\title{
KRYZYS EURO A HANDEL ZAGRANICZNY KRAJÓW UNII EUROPEJSKIEJ*
}

\section{WPROWADZENIE}

Kryzys finansowy, przez jaki przechodzą południowe kraje strefy euro oraz Irlandia, odbija się oczywiście na produkcji sektora realnego, jak również oddziałuje ujemnie na popyt importowy w krajach UE. Związki między kryzysem euro a produkcja sa jednak skomplikowane oraz mało przejrzyste. Łącznie ani cała Unia Europejska (UE-27), ani strefa euro (UE-17) nie cierpią np. na deficyt rachunku bieżącego bilansu płatniczego, który wymagałby podejmowania działań korekcyjnych. Jaki był wpływ kryzysu finansowego strefy euro na handel zagraniczny UE oraz jej pozycje w handlu światowym? Jakie były źródła tego kryzysu widzianego przez pryzmat kształtowania się bilansu płatniczego?

Osłabienie popytu wewnętrznego zmusza firmy do szukania rynków zbytu poza granicami kraju, czyli w tym wypadku UE. W jakim stopniu miało to miejsce w UE? Czy popyt na import z UE spadł bardziej aniżeli popyt importowy w reszcie świata? Czy nieraz słyszane opinie, że kredyty w euro finansowały eksport firm niemieckich, maja jakiekolwiek potwierdzenie w danych empirycznych? Czy fakt, że w reakcji na problem bilansu płatniczego niemożliwe było zastosowanie dewaluacji jako narzędzia polityki gospodarczej państw strefy euro, miał wpływ na ich eksport oraz import? Dostępne dane statystyczne handlu zagranicznego pozwalają na wstępne zarysowanie odpowiedzi na te pytania. Nie pozwalają one natomiast na analizę zmian postępu technicznego, jedynego źródła dobrobytu w krajach wysoko rozwiniętych pozbawionych bazy surowcowej oraz innych czynników kształtujących konkurencyjność firm krajowych. A zatem punkt ciężkości analizy przedstawionej poniżej spoczywa na analizie empirycznej ograniczonej do handlu zagranicznego w okresie po wejściu euro do obiegu pieniężnego krajów UE.

Przedmiotem analizy są nie tylko kraje strefy euro, lecz także wszystkie kraje Unii. Wprawdzie pierwotnie zamierzano skoncentrować się na krajach strefy euro, ale rozszerzenie liczby państw w tej strefie oraz brak zróżnicowania w ich wynikach handlu zagranicznego nie uzasadniają takiej dychotomii.

* Autorzy są wdzięczni prof. Janowi Winieckiemu za cenne, wnikliwe sugestie merytoryczne oraz redakcyjne. Wyrażają oni również podziękowanie prof. Markowi Ratajczykowi za bardzo użyteczne sugestie. Autorzy ponosza oczywiście odpowiedzialność za wszelkie błędy i niedociagnięcia w tekście artykułu. 
Wśród pierwotnych członków unii monetarnej w 1999 r. było 11 krajów, a obecnie jest ich 17. Grecja weszła w 2001 r., a dalsze pięć krajów przystąpiło znacznie później: Słowenia - w 2007 r., Cypr i Malta - w 2008 r., Słowacja w 2009 r. i Estonia - w 2011 r. ${ }^{1}$ Nie jest to zatem jednorodna grupa nie tylko z punktu widzenia terminów przystapienia, lecz także innych charakterystyk ekonomicznych. Jedyną homogeniczną grupą są byłe kraje członkowskie RWPG (Rady Wzajemnej Pomocy Gospodarczej) o gospodarce centralnie planowanej wszystkie zanotowały przeciętne stopy wzrostu eksportu przekraczające $10 \%$ w latach 2002-2011. Ich udział w eksporcie towarów UE-27 podwoił się, wzrósł z $6 \%$ do $12 \%$ w tym okresie. Pokazuje to, że inne czynniki aniżeli przyjęcie euro decydowały o ekspansji gospodarczej.

Jak zobaczymy, analiza danych empirycznych prowadzi do kilku zaskakujących obserwacji. Po pierwsze, kryzys w strefie euro nie miał istotnego wpływu na handel UE: pozycja UE $\mathrm{w}$ handlu globalnym nie uległa zmianie. Wahania $\mathrm{w}$ handlu światowym wywołane kryzysem globalnym nie były ani mniejsze, ani większe od zmian $\mathrm{w}$ wartości handlu UE. Po drugie, kryzys globalny nie odwrócił również tendencji rosnącej otwartości gospodarek państw członkowskich UE obserwowanej po 2000 r. Otwartość, mierzona udziałem eksportu w PKB, wzrosła wyraźnie dla wszystkich krajów UE. Wzrost gospodarczy w tym okresie nie był ciagniony przez popyt krajowy, ale przez popyt zewnętrzny, tj. zapotrzebowanie w innych krajach UE oraz reszty świata. Po trzecie, nie znaleziono danych empirycznych, które wsparłyby często wypowiadaną opinię, że tanie pożyczki w euro finansowały eksport Niemiec do krajów Południa. Wręcz przeciwnie, udział krajów Południa (Włoch, Hiszpanii, Portugalii oraz Grecji) w całkowitym eksporcie Niemiec kształtował się w pierwszej dekadzie XXI w. poniżej $15 \%$ i wykazywał tendencję spadkową. Wreszcie, po czwarte, członkostwo w unii monetarnej nie było katalizatorem wzrostu handlu. Dynamika handlu krajów, które wstąiły do UE w pierwszej dekadzie XXI w., była nieporównywalnie wyższa od dynamiki ,starych” członków UE.

\section{UNIA EUROPEJSKA W HANDLU ŚWIATOWYM: MIMO KRYZYSU NADAL POTEGGA}

Panujący nastrój kryzysu związany z percepcją niepewności przyszłości strefy euro nie miał specjalnego wpływu na kształtowanie się interakcji ekonomicznych na płaszczyźnie gospodarki Unii Europejskiej ani gospodarki światowej. Unia pozostała potęgą handlową, a stopień otwarcia jej gospodarki mierzony udziałem eksportu w produkcie brutto nie tylko nie spadł, ale wzrósł po załamaniu światowego handlu w $2008 \mathrm{r}$. Obroty zewnętrzne UE rosły szybciej od jej obrotów towarów i usług z resztą świata. W odróżnieniu od Stanów Zjednoczonych, które konsumują więcej, aniżeli produkują, produkcja

\footnotetext{
${ }^{1} \mathrm{~W}$ analizie poniższej będziemy rozróżniać UE-27 (czyli wszystkich obecnych członków UE bez względu na datę przystąpienia do Unii), UE-17 (czyli kraje obecnie należące do strefy euro) i UE-11 (czyli kraje strefy euro w 2002 r., czyli roku wejścia euro do obiegu pieniężnego).
} 
UE była większa od spożycia, choć od czasu do czasu odnotowywano mały deficyt na rachunku obrotów bieżących bilansu płatniczego.

\section{Szybki i zrównoważony wzrost sektora zewnętrznego UE}

Mimo spektakularnych wyników eksportowych Chin w tym okresie, których wartość eksportu rosła 20-30\% w pierwszych latach tego wieku, oraz 20-procentowego spadku wartości eksportu globalnego w 2009 r., udział Unii w eksporcie światowym dóbr i usług nie uległ większym zmianom w latach 2002-2011. Utrzymał się on na poziomie ok. $40 \%$ z lekka tendencja spadkowa między 2004 a 2009 r.; w 2009 r. eksport UE spadł w takim samym stopniu jak całkowity eksport światowy, znacznie bardziej spadł on w 2010 r., ale odbił się $\mathrm{z}$ nawiązką w $2011 \mathrm{r}$. Udział eksportu unijnego w światowym w latach 2002-2009 wynosił ok. 40\%, aby spaść do $35 \%$ w 2010 r., a następnie wzrosnąć do prawie $40 \% \mathrm{w} 2011 \mathrm{r}^{2}$

Lwia część handlu międzynarodowego przechodziła oraz nadal przechodzi przez kraje Unii Europejskiej, a w konsekwencji europejska dynamika tego handlu nadal kształtuje handel światowy, choć ta sytuacja się zmienia. Wyłączając UE, eksport pozostałej części świata rósł w latach 2002-2008 szybciej aniżeli eksport UE: przeciętna stopa wzrostu UE wynosiła 13,5\%, a świata bez UE równa była 15,9\% (tab. 1). Z drugiej jednak strony znaczenie UE pokazuje fakt, że w 2011 r. stopa wzrostu eksportu świata (bez UE) była ujemna i wynosiła 4,8\%. Dzięki 16-procentowemu wzrostowi eksportu z UE eksport światowy nie tylko nie spadł, ale wręcz wzrósł o prawie 3\% w $2011 \mathrm{r}$. (zob. tab. 1).

Kryzys nie odwrócił tendencji narastającej otwartości gospodarki UE mierzonej eksportem dóbr i usług w kategoriach procentu PB (produktu brutto). Wręcz przeciwnie, po spadku z 41\% w 2008 r. do $37 \%$ w 2009 r. eksport wzrósł do $41 \%$ PB w 2010 r. i $43 \%$ w 2011 r. Wzrost eksportu osiagnięto przede wszystkim dzięki wzrostowi eksportu na rynki krajów poza UE. Jak wynika $\mathrm{z}$ danych przedstawionych $\mathrm{w}$ tabeli 1 , udział eksportu do innych krajów UE spadł z przeciętnej $67,4 \%$ dla lat $2002-2008$ do $66 \%$ w 2009 r., $64 \%$ w 2010 r., oraz 63\% w 2011 r. W latach 2010 i 2011 nie było to wynikiem spadku eksportu wewnętrznego krajów UE, gdyż ten wzrósł o 10\% w 2010 r. oraz 14\% rok później.

Pojawienie się nadwyżki na rachunku obrotów bieżących zagregowanego bilansu płatniczego UE w 2011 r. nie sygnalizuje nowej tendencji, ponieważ jedyną tendencja zaobserwowaną w latach 2002-2008 były olbrzymie wahania między deficytem sięgającym 182 mld dolarów w 2008 r. a nadwyżką 56 mld dolarów w 2004 r. Deficyt nie przekraczał 1\% PKB Unii Europejskiej nawet w szczytowym 2008 r. Eksport netto mierzony stosunkiem różnicy między wartością eksportu a wartością importu do sumy obrotów zewnętrznych (tj. sumy eksportu oraz importu) wahał się między $0,2 \%$ w 2008 r. a $2,1 \%$

\footnotetext{
${ }^{2}$ Wyłączając handel wewnętrzny krajów UE, udział tych krajów w imporcie światowym był wyjątkowo stabilny - na poziomie $20 \%$ w latach 2001-2011. Udział w eksporcie światowym natomiast wahał się między $19 \%$ w 2010 r. a $22 \%$ w latach 2001-2004. W 2011 r. wynosił on $21 \%$ (obliczenia własne na podstawie danych Comtrade).
} 
Tabela 1

Podstawowe charakterystyki sektora zewnętrznego Unii Europejskiej w latach 2002-2011 (w mld dolarów USA i procentach)

\begin{tabular}{|c|c|c|c|c|}
\hline & $\begin{array}{c}\text { Przeciętna } \\
\text { w 2002-2008 }\end{array}$ & 2009 & 2010 & 2011 \\
\hline $\begin{array}{l}\text { Rachunek bieżący (mld dolarów USA) } \\
\text { Rachunek bieżący w procencie PKB } \\
\text { Eksport DiU w procencie ich importu } \\
\text { Eksport DiU w procencie PKB } \\
\text { Eksport DiU netto (bilans handlu } \\
\text { przez całkowity obrót) }\end{array}$ & $\begin{array}{r}-37,897 \\
-0,270 \\
101,900 \\
38,100 \\
1,1 \%\end{array}$ & $\begin{array}{r}-3,895 \\
-0,020 \\
102,700 \\
36,800 \\
1,4 \%\end{array}$ & $\begin{array}{r}-13,847 \\
-0,090 \\
102,200 \\
40,500 \\
1,1 \%\end{array}$ & $\begin{array}{r}31,502 \\
0,180 \\
102,500 \\
43,400 \\
\\
1,2 \%\end{array}$ \\
\hline Memorandum: & & & & \\
\hline $\begin{array}{l}\text { Stopa wzrostu eksportu UE } \\
\text { Stopa wzrostu eksportu światowego } \\
\text { Stopa wzrostu eksportu światowego } \\
\text { bez UE } \\
\text { Udział eksportu wewnętrznego } \\
\text { w eksporcie UE }\end{array}$ & $\begin{array}{l}13,5 \\
14,8 \\
15,9 \\
67,4\end{array}$ & $\begin{array}{l}-20,4 \\
-20,2 \\
-20,1 \\
65,9\end{array}$ & $\begin{array}{r}9,1 \\
19,5 \\
25,9 \\
64,4\end{array}$ & $\begin{array}{r}16,4 \\
2,6 \\
-4,8 \\
63,2\end{array}$ \\
\hline
\end{tabular}

Źródło: obliczenia własne na podstawie danych UN Comtrade oraz World Bank Development Indicators.

w 2002 r. i nie był ujemny w dekadzie 2000-2009. Eksport generował dochód zapewniający pokrycie wydatków związanych z zakupami importowymi: wartość eksportu dóbr i usług (DiU) przekraczała wartość importu we wszystkich latach okresu 2002-2011. Jak wynika z danych zawartych w tabeli 1 , wartość eksportu była przeciętnie o ok. $2 \%$ wyższa od importu w latach 2002-2008 ${ }^{3}$. Wahania były niewielkie - poniżej 5\%: między 100\% w 2008 r. a $104 \%$ w 2002 r.

\section{Rosnaca rola handlu usługami: nadwyżka pokrywa deficyt handlu dobrami}

Drugą tendencją, której kryzys nie tylko nie odwrócił, ale wręcz przyspieszył, był szybszy wzrost eksportu usług aniżeli eksportu dóbr. Eksport netto usług wzrósł z 3,35\% w 2002 r. do 9,45\% w 2011 r. W 2005 r. Unia stała się importerem netto dóbr. Dzięki wzrostowi udziału usług w całkowitym eksporcie z 23,5\% w latach 2002-2003 do 24,5\% w 2008 r. oraz rosnącej nadwyżce $\mathrm{w}$ handlu usługami Unia utrzymała status eksportera netto dóbr i usług (tab. 2).

Rosnąca nadwyżka w handlu usługami nie tylko zrekompensowała wzrost deficytu w obrotach towarowych, lecz także osłabiła negatywny wpływ kryzysu w 2009 r. Załamanie eksportu usług było znacznie mniejsze aniżeli eksportu

\footnotetext{
${ }^{3}$ W konwencji statystyk handlu międzynarodowego wartość importu zawiera koszt transportu oraz ubezpieczenia, podczas gdy w wartości eksportu wielkości tych się nie uwzględnia.
} 


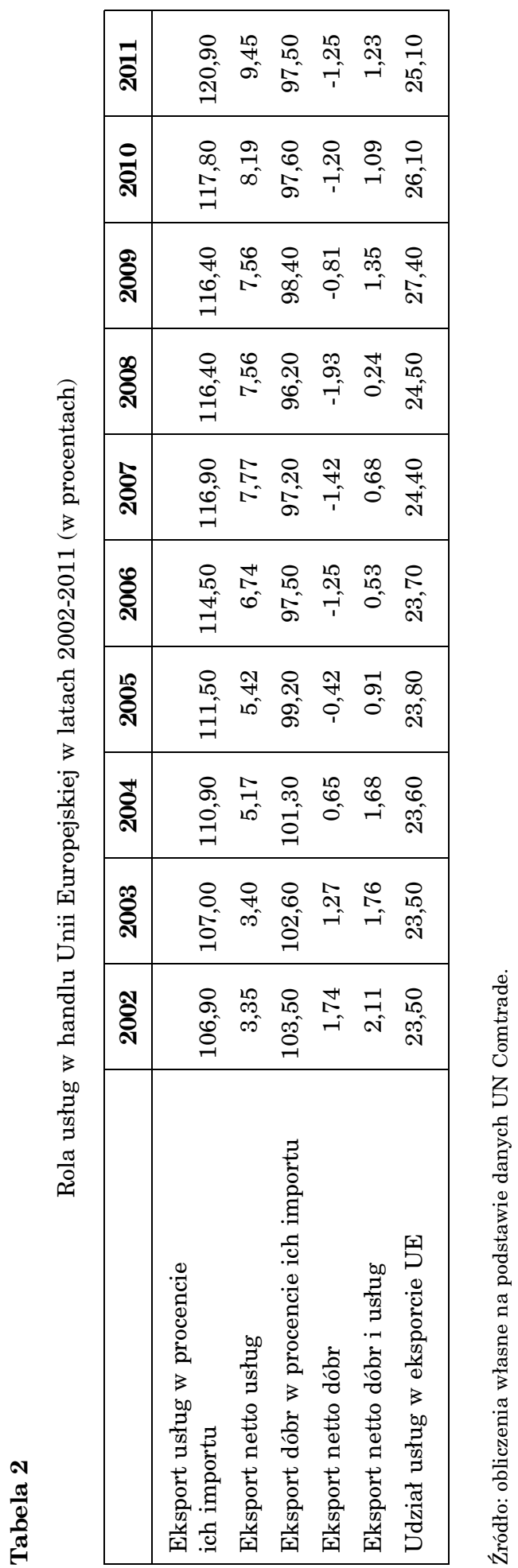


dóbr w 2009 r., ale też „odbicie” w eksporcie towarowym było większe i w rezultacie udział usług spadł z 27\% w 2009 r. do $25 \%$ w 2011 r., nadal powyżej poziomów osiaganych w przeszłości.

Z powyższych danych nie należy wyciagać wniosku, że eksport dóbr będzie tracił na znaczeniu. Jak widać wyraźnie na poniższym wykresie, dominują one nadal w eksporcie pochodzącym z Unii, choć okazały się znacznie bardziej wrażliwe na globalny kryzys 2009 r. (zob. wykres 1). W roku tym wartość eksportu usług spadła o 11\%, podczas gdy eksport dóbr obniżył się o $23 \%$.

\section{Wykres 1}

Eksport dóbr i usług przez Unię Europejską w latach 2002-2011 (w mld dolarów USA)

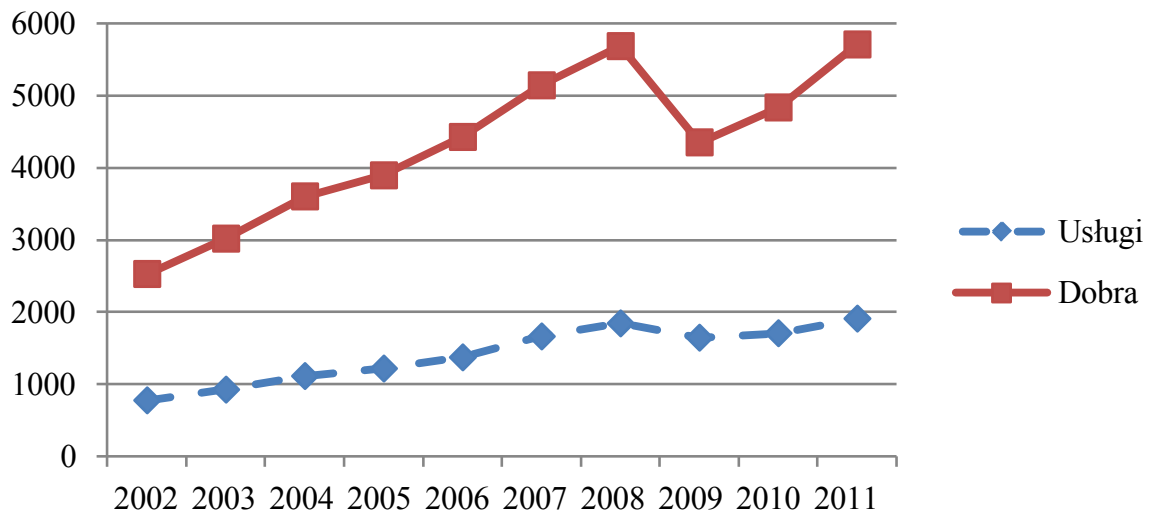

Źródło: obliczenia własne na podstawie danych UN Comtrade.

Nie powinno to jednak sugerować, że Unia utraciła przewagę konkurencyjną w produkcji dóbr o wysokiej zawartości technologii. Eksport produktów wysokiej technologii miał - z pewnymi odchyleniami - bardzo podobny profil jak całkowity eksport dóbr. Udział Unii w światowym eksporcie tych produktów pozostał na poziomie nieznacznie wyższym od udziału w eksporcie całkowitym. Zważywszy, że wschodzące gospodarki krajów Azji w coraz większym stopniu wchodzą w produkcje dóbr charakteryzujących się rosnąca zawartością wiedzy czy też technologii, a krajów UE nie charakteryzuje kreatywna destrukcja na poziomie amerykańskim, jest to imponujące osiągnięcie, potwierdzające wysokie zdolności konkurencyjne europejskich firm o wysokiej technologii na rynkach światowych ${ }^{4}$.

${ }^{4}$ „The Economist” zidentyfikował tylko jedno przedsiębiorstwo założone między 1976 a 2003 r. w Europie, któremu udało się osiągnąć podobny sukces jak firmom Microsoft czy też Apple. Przedsiębiorstwem tym jest Renewable Energy Corporation, założone w Norwegii, która nie jest członkiem UE (za: E. E. Prescott, L. E. Ohanian, Taxes Are Much Higher than You Think, „The Wall Street Journal", December 12, 2012). Na podstawie statystycznej analizy handlu zagranicznego z uwzględnieniem ,nowoczesności” usług oraz produktów podobny wniosek wyciagają autorzy raportu Banku Światowego (I. Gil, M. Raiser, Golden Growth: Restoring the Lustre of the European Economic Model, World Bank, Washington, DC, 2012). 


\section{Unia a reszta świata: ekspansja handlu „zewnętrznego”}

Mimo tzw. rozszerzenia wschodniego UE w latach 2004-2007 oraz wprowadzenia euro w 1999 r. zarówno eksport, jak i import spoza krajów UE rósł szybciej od wymiany wewnątrz wspólnoty: średnia stopa wzrostu eksportu do reszty świata (RS) wyniosła 9,4\% w latach 2002-2010, a w ramach UE wzrost eksportu wyniósł 7,8\%. Wzrost importu z RS, który wyniósł 10,1\%, był również szybszy od średniej stopy wzrostu importu wewnątrz UE wynoszącej 7,9\%. W rezultacie udział RS w eksporcie UE wzrósł z 32\% w 2001 r. do 36\% w 2012 r., a w imporcie - z $49 \%$ do $54 \%$ w tym samym okresie.

\section{Wstępne konkluzje}

Jaki obraz wyłania się z analizy wyników działalności „zewnętrznej” Unii, traktowanej jako jednolity organizm gospodarczy? Trzy obserwacje kreślą kontury tego obrazu. Po pierwsze, wprawdzie globalny kryzys finansowy wywołał załamanie handlu światowego, ale UE jako całość nie została nim dotknięta w stopniu większym niż reszta świata. Zarówno załamanie handlu w 2009 r., jak i ożywienie w latach 2010 i 2011 nie odbiegały znacznie od dynamiki światowej. Po drugie, kryzys nie zmienił wcześniej obserwowalnych tendencji: stopień otwartości UE nadal wzrasta; udział usług w całkowitym eksporcie rośnie. Tak samo jak udział gospodarek spoza UE w eksporcie krajów wspólnoty. Po trzecie, UE nadal jest potęgą w handlu międzynarodowym - jej udział zarówno w eksporcie, jak i imporcie wynosi ponad jedną trzecia. Wprawdzie pojawiają się nowi konkurenci, ale firmy krajów UE wykazują nadal wysokie zdolności adaptacyjne oraz konkurencyjne.

Krótko mówiąc: kryzys $\mathrm{w}$ handlu globalnym należy do historii, a UE przetrwała ten kryzys ani nie lepiej, ani nie gorzej od innych krajów świata. Gdyby spojrzał na to przybysz z Marsa, to na podstawie danych skonsolidowanego bilansu płatniczego UE pochwaliłby jej „rząd” za ostrożną politykę zewnętrzną, niedopuszczająca do powstawania zewnętrznych nierównowag. Natomiast kryzys strefy euro umknąłby zupełnie jego uwadze.

Nasuwa się więc pytanie: Czy mając informacje o eksporcie i innych wynikach zewnętrznych na poziomie gospodarek narodowych, moglibyśmy rozróżnić gospodarki, które przyjęły euro, i te, które pozostały poza strefa euro? Pomijając, że tak wiele innych czynników wyznacza konkurencyjność gospodarek narodowych operujących w ramach jednolitego rynku na towary, usługi, prace i kapitał, odpowiedź na to pytanie nie wniosłaby dodatkowych elementów do oceny czynników, które zadecydowały o wynikach handlu zagranicznego UE. Ale w związku z tym, że wyniki te są prostym zsumowaniem wyników osiagniętych na szczeblu gospodarek narodowych, ich omówienie, które jest przedmiotem następnej części, pozwala na zidentyfikowanie krajów determinujących dynamikę całości, a tym samym może rzucić światło na kształtowanie się tendencji w przyszłości oraz rolę, jaką odegrało wprowadzenie euro. 


\section{RÓŻNORODNOŚĆ GOSPODAREK NARODOWYCH UE: JEDNA CZY WIELE EUROP W UE?}

Większość krajów UE eksportowała mniej dóbr i usług aniżeli importowała. Arytmetyczna większość nie spowodowała skonsolidowanego deficytu w obrotach bieżących bilansu płatniczego ani też w bilansie handlowym z prostego powodu: największe kraje UE miały albo niewielkie deficyty, albo też znaczne nadwyżki w obrotach zewnętrznych. Wśród tych ostatnich najważniejsze to Niemcy, a w dalszej kolejności kraje skandynawskie oraz Beneluksu. Ich łączne nadwyżki w decydującej mierze zredukowały nadmierna, w stosunku do ich produkcji, konsumpcję pozostałych krajów członkowskich UE.

\section{Równowaga całości UE nie przekłada się na równowagi na szczeblu gospodarek narodowych}

Choć deficyt rachunku bieżącego, w znacznej mierze wyznaczany przez bilans obrotów handlu zagranicznego, zawsze oznacza nadwyżkę krajowej konsumpcji nad produkcją, implikacje dla przyszłej pozycji zewnętrznej kraju zależą od tego, co stanowi tę nadwyżkę, czyli jak się ją użytkuje. Jeśli nadwyżka jest wynikiem inwestycji zagranicznych, których napływ z definicji wywołuje presje w kierunku deficytu rachunku bieżącego, to przynajmniej w odniesieniu do krajów członkowskich UE można założyć, że tworzą one nowe zdolności generowania strumieni dochodów w przyszłości ze sprzedaży zarówno na rynkach krajowych, jak i zagranicznych.

W tabeli 3 zebrano informacje dotyczące sald na rachunku bieżącym w procentach PKB oraz zakresu, w jakim wpływy z eksportu dóbr i usług pokrywaja wydatki na ich import. Ponadto dla obydwu elementów rachunku bieżącego obliczono odpowiednie wartości zagregowane dla okresu dziesięciu lat, czyli sumy sald na rachunku bieżącym. Kraje uporządkowano od najniższej do najwyższej wartości pokrycia importu DiU ich eksportem w latach 2002-2011 lub, innymi słowy, kraje uporządkowano według salda bilansu handlowego od największych deficytów do najwyższych nadwyżek: na jednym krańcu jest Grecja z pokryciem importu w 67\%, a na drugim - Luksemburg z pokryciem importu w $122 \%$.

Wśród grupy „deficytowej” o pokryciu importu eksportem poniżej 90\% w latach 2002-2011 znajdują się zarówno starzy członkowie UE (Grecja, Portugalia, Hiszpania), jak i kraje z ostatniej fali rozszerzenia (Bułgaria i Rumunia z 2007 r., Łotwa i Cypr przyjęte w 2004 r.). Spośród tych siedmiu krajów, dwóm - Bułgarii oraz Grecji - udało się finansować skumulowany deficyt na rachunku bieżącym przekraczający $10 \%$ PKB.

W wypadku Bułgarii, jak również Hiszpanii, Portugalii, Rumunii i Łotwy, spadek był zbyt gwałtowny, aby można go było wytłumaczyć finansowaniem z innych źródeł (tzn. pożyczki rządowe na rynkach prywatnych). Kwestia Cypru nie jest jasna ze względu na jego specjalizację w usługach finansowych, które są na ogół trudne do uchwycenia w statystykach międzynarodowych, choć dane o długu publicznym sugeruja finansowanie konsumpcji przez pożyczki 


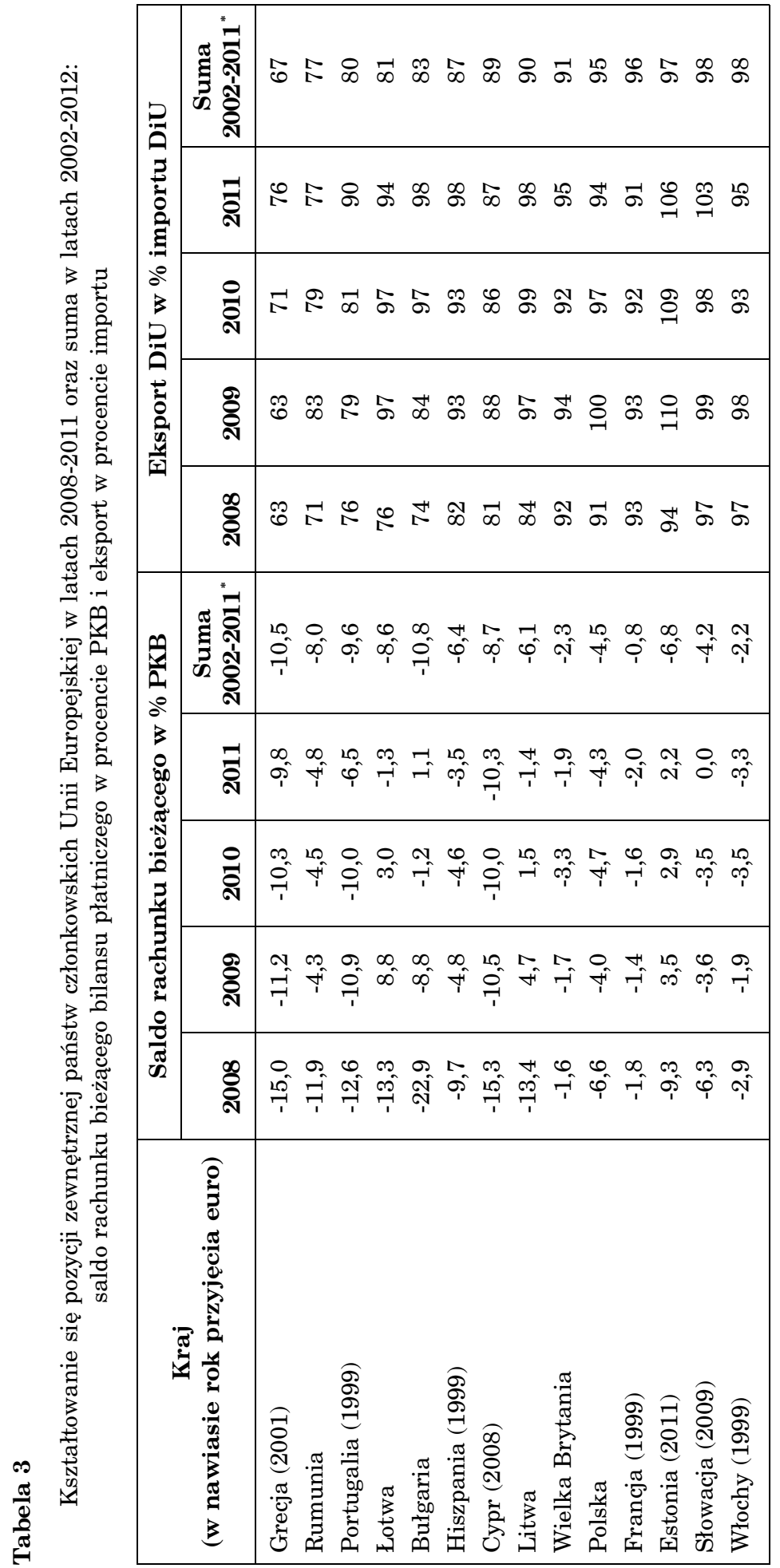




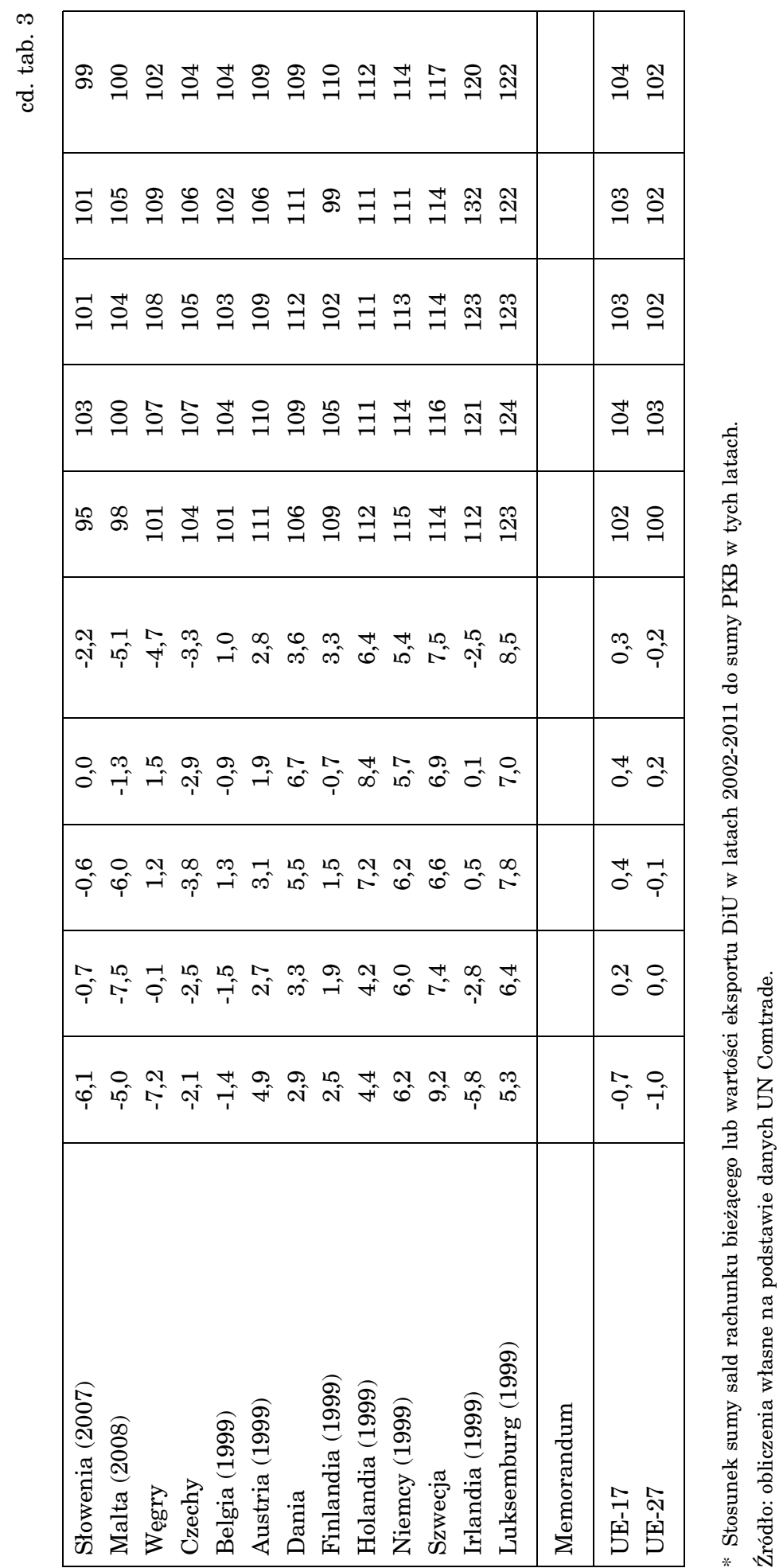


rządowe ${ }^{5}$. Natomiast deficyty Grecji wiązały się z nadmierną konsumpcja $\mathrm{w}$ stosunku do krajowej produkcji dóbr i usług, finansowana głównie pożyczkami zaciąganymi przez rząd, korzystajacy $\mathrm{z}$ braku ryzyka wymiany waluty oraz niskich stóp procentowych determinowanych na rynkach największych krajów strefy euro - Niemiec i Francji.

Grupa „nadwyżkowa” o pokryciu importu przekraczającym jego wartość (o co najmniej 5\%) jest liczniejsza i obejmuje ona 8 spośród 27 krajów członkowskich. Należą do niej wszystkie kraje, które wstąpiły do Unii w 1995 r. (Austria, Finlandia, Szwecja); trzy, które były wśród sześciu podpisujących traktaty rzymskie w 1957 r. (Holandia, Niemcy, Luksemburg), oraz dwa kraje z rozszerzenia Wspólnoty w 1973 r. (Dania, Irlandia). Obecność Irlandii w tej grupie może się wydać nieporozumieniem, ale wyniki zewnętrzne predestynują Irlandię do tej, a nie innej pozycji. Z wyjątkiem Danii i Szwecji pozostałe kraje są częścią strefy euro.

W sumie gospodarki krajów członkowskich UE są wysoce zróżnicowane, choć dane $\mathrm{w}$ tabeli 3 wskazują na jedną cechę, a mianowicie: wyraźną poprawę wyników zewnętrznych w 2011 r. Z wyjątkiem Cypru (którego deficyt na saldzie obrotów bieżących bilansu płatniczego w 2011 r. był wyższy niż wielkość wynikająca z sumowania deficytów oraz PKB w latach 2002-2011) oraz Finlandii pozostałe kraje zarejestrowały poprawę bądź też nieznaczny spadek nadwyżek. W wypadku Finlandii nie ma to większego znaczenia, gdyż ma to miejsce w kontekście tradycyjnie wysokich nadwyżek. Natomiast jeśli chodzi o porównanie odpowiednich wielkości finansowania importu DiU ich eksportem, niepokojący jest dość gwałtowny spadek tego wskaźnika dla dwóch potentatów unijnych - Francji oraz Włoch. Interesujące, że luka jest większa w wypadku handlu Francji. Bez przyjrzenia się bliżej dynamice eksportu nie można wysnuć dalej idących wniosków.

Dane te nie dostarczaja empirycznego potwierdzenia często spotykanej opinii, że problemem Europy nie jest zbyt rozbuchany sektor publiczny czy też „,stłamszony” sektor prywatny krajów zadłużonych, ale raczej kryzys jest wynikiem ,,...] fundamentalnego braku równowagi wewnątrz strefy pojedynczej waluty, w której stosuje się jednolitą politykę monetarną oraz jeden kurs wymienny do bardzo zróżnicowanej grupy krajów" ${ }^{6}$. Nasuwają się trzy uwagi podważające zasadność diagnozy Moravcsika: Pierwsza to, że pojawienie się „dwóch Europ” w ramach UE poprzedziło wprowadzenie euro. David Roche prawie dziesięć lat temu, omawiając perspektywy rozwoju gospodarczego UE, wskazał na pojawienia się dwóch Europ: jednej skupionej wokół Niemiec i drugiej, mniej zdyscyplinowanej Europy Południa ${ }^{7}$. Pierwsza to kraje reformujące się, poszukujące najlepszych sposobów sprostania konkurencji globalnej, a druga to kraje „miękkiego pieniądza”, które będą tracić swoją pozycję konkurencyjną.

${ }^{5}$ Wprawdzie z wyjątkiem Szwecji dług publiczny w procentach PKB wzrósł bardzo znacznie w wypadku wszystkich krajów UE, wzrost ten nie był jednak taki sam. Wystąpiły znaczne różnice między poszczególnymi państwami: dług publiczny Cypru wzrósł z 49\% PKB w 2008 r. do $71 \%$ w 2011 r., natomiast dług Malty z 63 do $71 \%$ (dane Eurostatu).

${ }^{6}$ A. Moravcsik, Europe after the Crisis, „Foreign Affairs” 2012, May-June, s. 54-55.

7 D. Roche, You Ain't Seen Nothing Yet, ,Euromoney” 1994, June. 
Druga uwaga jest następująca: Niemcy nie stały się gospodarką nadwyżek eksportowych po wprowadzeniu euro w 1999 r. Stały się nią już w latach sześćdziesiątych, a lata siedemdziesiąte upływały pod znakiem ciągłych nacisków w kierunku rewaluacji marki zachodnioniemieckiej ${ }^{8}$. Czy wprowadzenie euro pomogło w kontynuacji nadwyżek eksportowych? Zapewne tak, ale nie był to czynnik decydujacy.

Wreszcie, po trzecie, jak zobaczymy poniżej, eksport Grecji rósł szybciej od eksportu Niemiec, a najszybciej wzrastał eksport z krajów, który wstąpiły do Unii w 2004 i 2007 r. Większość z nich albo jeszcze nie stała się częścią strefy euro, albo też przystapiła do unii monetarnej pod koniec pierwszej dekady XXI w. A co więcej Szwecja (kraj spoza strefy euro) czy Holandia (w strefie euro) miały wyższe nadwyżki obrotów bieżących niż pozostałe kraje członkowskie UE w pierwszej dekadzie tego wieku. Tak więc nader trudno jest wiązać różnice $\mathrm{w}$ wynikach ich działalności zewnętrznej z optimum strefy monetarnej.

\section{Dynamika eksportu: eksport nowych państw członkowskich rósł najszybciej}

Francja jest na szarym końcu, jeśli chodzi o wzrost eksportu w latach 2002-2011, a Włochy znajdują się jedynie o trzy pozycje wyżej w hierarchii krajów UE uporządkowanej według przeciętnego wzrostu eksportu DiU (zob. tab. 4). Francja, tradycyjny eksporter wyrobów przemysłowych, przesuwa się $\mathrm{w}$ kierunku eksportu usług. Jest to tendencja charakterystyczna dla najwyżej rozwiniętych krajów UE, choć z pewnymi wyjątkami - Włochy i Holandia zanotowały szybszy wzrost eksportu towarów aniżeli usług. Interesujące, że również to samo dotyczy kształtowania się dynamiki wzrostu eksportu greckiego.

Jak widać $\mathrm{z}$ danych prezentowanych $\mathrm{w}$ tabeli 4, niektóre kraje $\mathrm{z}$ tzw. rozszerzenia wschodniego UE również zanotowały szybszy wzrost eksportu usług aniżeli eksportu dóbr. Kraje te to Rumunia, Polska, Czechy oraz Słowenia.

Średni wzrost eksportu wszystkich krajów UE w latach 2002-2011, mimo załamania w 2009 r., był dwucyfrowy, przekraczający $10 \%{ }^{9}$. Przyjmując za punkt odniesienia przeciętna stopę wzrostu światowego eksportu dóbr i usług, można rozróżnić kraje, które zwiększyły udział w handlu światowym, i pozostałe. W pierwszej grupie znalazło się 12 krajów UE: 10 krajów z tzw. rozszerzenia wschodniego lat 2004 i 2007 oraz Luksemburg i Grecja. Wartość eksportu każdego $\mathrm{z}$ tych krajów wzrósł ponad dwukrotnie (2,3 dla Grecji) oraz prawie pięciokrotnie (4,5 w wypadku Bułgarii).

W rezultacie, z wyjatkiem Grecji i Rumunii, kraje te uzyskały niesłychanie wysoki poziom otwartości gospodarek mierzony eksportem dóbr i usług,

${ }^{8}$ E. Kantzenbach, Germany's International Competitiveness: Germany as a Business Location, „Intereconomics” 1994, January-February.

${ }^{9}$ Zważywszy na deprecjacje w pierwszej dekadzie obecnego stulecia walut światowych - dolara oraz euro - dynamika handlu w cenach bieżących jest wyjątkowo wysoka. Nie zmienia to jednak faktu, że lata 2002-2008 były złotym okresem dla handlu światowego: jego wzrost był bez precedensu. 


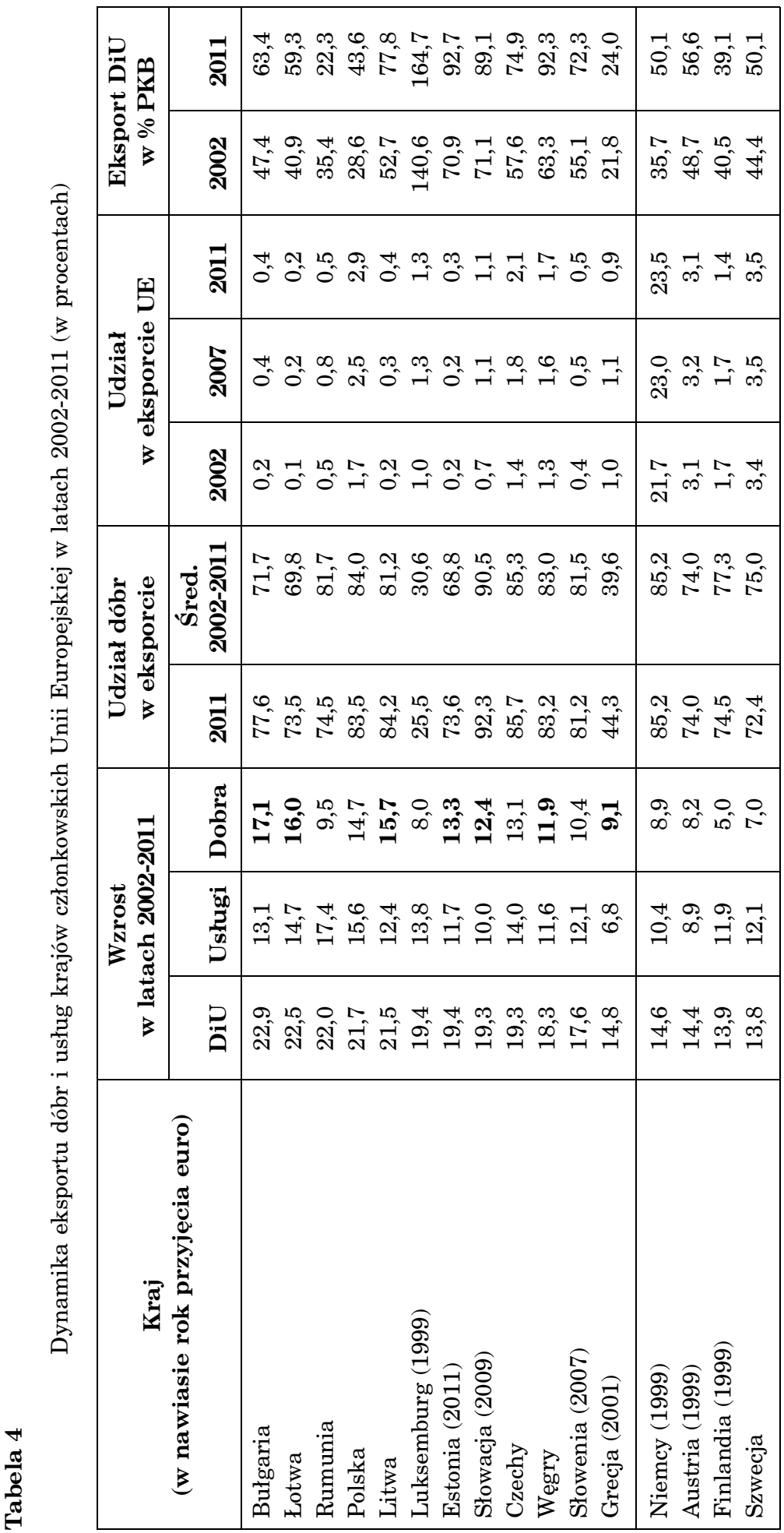




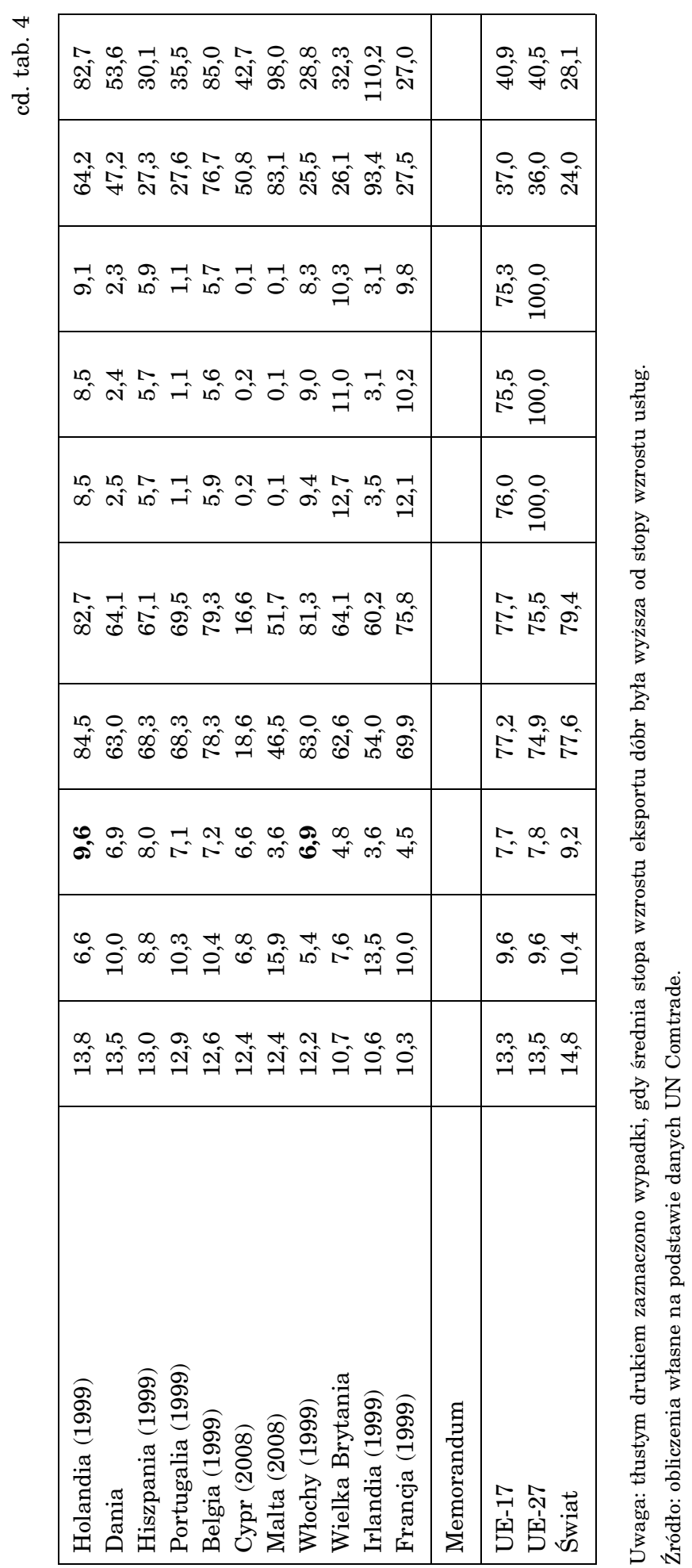


wyrażonym w procencie PKB. Wzrósł on również bardzo znacznie w wypadku Niemiec, których stopa wzrostu eksportu $14,6 \%$ była tylko o 0,2 punktu procentowego poniżej średniej światowej. Udział eksportu w PKB Niemiec wzrósł z 36\% w 2002 r. do 50\%, czyli dwa razy więcej niż w wypadku niewielkiej Grecji!

Nie tyle uczestnictwo w strefie euro, ile data wstapienia do UE była główna determinanta poziomu integracji z rynkami europejskimi i globalnymi. Pomijając Maltę i Cypr, pozostałe kraje, które stały się członkami Unii w 2004 i 2007 r. odnotowały imponująca ekspansję handlu zagranicznego przed wstapieniem i po wstąpieniu do UE. Wartość eksportu dóbr dziesięciu krajów tzw. rozszerzenia wschodniego wzrosła ponad trzykrotnie $(3,6) \mathrm{w}$ latach 2002-2011, podczas gdy łączna wartość eksportu pozostałych członków UE wzrosła w tym czasie ponad dwukrotnie $(2,2)$. Udział tych dziesięciu państw w eksporcie UE wzrósł z 7\% w 2002 r. do 11\% w latach 2010-2011.

Dynamika eksportu pierwotnych 11 członków strefy euro była przeciętnie prawie jeden punkt procentowy niższa aniżeli całkowity eksport pozostałych krajów UE: stopa wzrostu dla lat 2002-2011 wynosiła 8\% dla UE-11 i 8,8\% dla pozostałych krajów Unii. Choć niemożliwe jest ustalenie związku przyczynowego, a jedynie można wskazać na zjawisko współwystępowania, przyjęciu euro nie towarzyszył nagły wzrost eksportu do innych krajów strefy euro. Wyższa dynamika eksportu krajów spoza strefy euro była wynikiem ich niższego poziomu rozwoju i związanego z tym mechanizmu doganiania (catching-up) ułatwionego przyjęciem wyższej jakości instytucji oraz integracja z jednolitym rynkiem, co m.in. spowodowało znaczny napływ bezpośrednich inwestycji zagranicznych $\mathrm{w}$ drugiej połowie lat dziewięćdziesiątych i doprowadziło do modernizacji aparatu wytwórczego.

Wyrównywanie się temp wzrostu w latach 2009-2011 może sugerować, że rezerwy wzrostowe są na wyczerpaniu. W terminologii stadiów wzrostu gospodarczego używanej przez autorów raportu „Konkurencyjność globalna”, corocznie publikowanego przez Genewskie Światowe Forum Gospodarcze, większość $\mathrm{z}$ tych krajów była $\mathrm{w}$ tym czasie na poziomie wzrostu napędzanego wydajnością bądź też przejścia do fazy wzrostu napędzanego innowacjami ${ }^{10}$. W tych fazach, w których wzrost napędza wzrost wykorzystania czynników produkcji, łatwiej jest uzyskać wyższą dynamikę aniżeli wówczas, gdy główną siła sa innowacje. A więc istnieje realne niebezpieczeństwo, że moga one przestać być siła napędzającą wzrost eksportu UE.

\section{Załamanie w 2009 r.: dostosowanie a kryzys strefy euro}

Kraje Europy Środkowo-Wschodniej również lepiej przetrwały aniżeli inne kraje UE wielkie załamanie popytu importowego w 2009 r., który w wymiarze światowym spadł o $20 \%$, a dla tych krajów - 26\%. Spadek ten został jednak szybko zrekompensowany wzrostem eksportu. Całkowita wartość eksportu

10 Zob. The Global Competitiveness Report, 2010-11, The World Economic Forum, Geneva 2010; X. Sala-I-Martin et al., Chapter 1.1., w: Global Competitiveness Report, 2008-09, The World Economic Forum, Geneva 2009. 
dóbr z tych krajów była w 2011 r. o $17 \%$ wyższa od ich wartości w przedkryzysowym roku 2008. Spadek eksportu pozostałych krajów UE był mniejszy: wyniósł on $23 \%$, ale wzrost też był słabszy. Wartość eksportu tych ostatnich w 2011 r. była jeszcze minimalnie $(0,1 \%)$ niższa aniżeli w 2008 r.

$\mathrm{Z}$ wyjątkiem Irlandii, której eksport spadł jedynie o 8\% w 2009 r., wszystkie inne kraje odnotowały spadki znacznie poniżej $10 \%$. Ani wielkość spadku, ani też szybkość wyjścia z zapaści nie wydają się mieć nic wspólnego z kryzysem strefy euro. Kraje tzw. PIIGS, które stały się synonimem kryzysu strefy euro (Portugalia, Włochy, Irlandia, Grecja, Hiszpania), zostały dotknięte załamaniem handlu światowego bardzo nierównomiernie. Poza wspomnianą Irlandią, która odnotowała minimalny spadek popytu zagranicznego na dobra i usługi Made in Ireland, eksport z Grecji spadł o 25\%, Włoch - 24\%, Portugali - 20\%, a Hiszpanii - 18\%. Załamanie eksportu krajów Półwyspu Iberyjskiego było poniżej średniej światowej wynoszącej 20,2\%. Z wyjątkiem Grecji (13 punktów procentowych) oraz Włoch (4 punkty procentowe) wartość eksportu DiU innych krajów PIIGS była w 2011 r. powyżej najwyższego poziomu przedkryzysowego w 2009 r. (zob. tab. 5).

Kraje tzw. rozszerzenia wschodniego UE wykazały największa zdolność adaptacji do trudniejszych warunków na rynkach światowych po 2009 r. Wśród 10 krajów, których wartość eksportu była ponad 5\% powyżej najwyższego poziomu sprzed kryzysu, znalazło się siedem krajów Europy Środkowo-Wschodniej (trzy kraje bałtyckie, Bułgaria, Czechy, Polska i Słowacja) oraz Malta. Pozostałe dwa kraje to Irlandia i Hiszpania. Natomiast wśród krajów, których eksport był 5\% lub mniej poniżej poziomu szczytowego, były Grecja i Cypr oraz Finlandia i Rumunia.

O ile eksport odbił się od dna relatywnie szybko, o tyle popyt importowy krajów UE pozostał w tyle. Jedynie pięć krajów miało import o 5\% lub więcej wyższy aniżeli w szczytowym roku przedkryzysowym - Estonia, Czechy, Malta, Niemcy i Holandia. Natomiast aż 11 krajów importowało w 2011 r. o 5\% lub mniej aniżeli w 2008 r. Największy spadek odnotowano w Rumunii oraz Grecji import w $2011 \mathrm{r}$. był w nich odpowiednio na poziomie $60 \%$ oraz $71 \%$ rekordowego poziomu przedkryzysowego. Jeśli chodzi o kraje PIIGS, to pomijając wspomnianą wyżej Grecję, wyniki były zróżnicowane: konsumpcja dóbr i usług z importu osiągnęła we Włoszech 98\% poziomu przedkryzysowego, w Portugalii $-87 \%$, w Irlandii - 93\%, a w Hiszpanii - 89\%.

Kraje PIIGS nie były jedyną grupą krajów UE, które padły ofiara globalnego kryzysu finansowego lat 2007-2009. Inna grupa to kraje spoza strefy euro, przynajmniej w 2009 r. W skrócie można ją określić - zapożyczając określenie użyte przez Leszka Balcerowicza w wywiadzie dla „The Wall Street Journal” z 15 grudnia 2012 r. -jako grupę BELL, czyli Bułgaria, Estonia, Litwa i Łotwa. Eksport z tych krajów spadł między 26\% (Estonia) a 21\% (Łotwa). Litwa i Estonia, obok Finlandii i Szwecji, doświadczyły największego szoku zewnętrznego spośród krajów UE. Dokonały one również największych cięć w imporcie, znacznie przekraczających spadek eksportu, w celu obniżenia deficytu w bilansie handlowym. Wartość importu Litwy, Łotwy oraz Estonii spadła prawie o 40\%, a Bułgarii -jedną trzecią. W odróżnieniu od krajów PIIGS, 
z wyjątkiem Bułgarii i w mniejszym stopniu Łotwy, wartość importu tych państw w 2011 r. była wyższa aniżeli przed kryzysem roku 2009.

Różnice między spadkiem eksportu a spadkiem importu podczas kryzysu w 2008 r. rzucaja światło na zakres dostosowania wywołanego globalnym kryzysem finansowym lat 2007-2008. Kraje BELL przeszły największą terapię dostosowawczą: dla państw bałtyckich różnica wynosiła ponad 10 punktów procentowych, a dla Bułgarii - 9,4 punktu. Odbyło się to kosztem cięć importowych. Dla Hiszpanii wahnięcie wynosiło 9,5 punktu procentowego, Irlandii $-6,4$, a Portugalii - 2,9 punktu procentowego. Najmniejsze dostosowanie po stronie importu miało miejsce w wypadku Grecji - spadek importu był na poziomie spadku eksportu. Porównanie profili dostosowania państw BELL i PIIGS sugeruje, że euro dostarczyło osłony, ale tylko tym krajom, które chciały z tego skorzystać. Ceną może stać się bardziej kosztowny i dłuższy proces dostosowawczy z negatywnymi implikacjami dla ich przyszłej konkurencyjności.

\section{Konkluzja - dwie, a nie jedna Europa w UE?}

Pomijając zróżnicowanie gospodarek krajów członkowskich, z analizy powyższej wynika, że istnieje przynajmniej jedna grupa krajów charakteryzujących się dynamicznie zmieniającym się profilem specjalizacji. W grupie tej - oprócz krajów skandynawskich, Holandii, Irlandii, Niemiec - znajdują się kraje tzw. rozszerzenia wschodniego, z wyjątkiem Cypru i Rumunii (choć ocena co do Rumunii pozostaje nierozstrzygnięta) ${ }^{11}$. Całkowitym przeciwieństwem tej grupy sa Cypr i Grecja. Grecja uzyskała niezłe wyniki w dynamice eksportu, ale z bardzo niskiego poziomu i nadal eksport wyrażony w procentach PKB jest żenująco niski. A w wypadku Cypru eksport wyrażony w procentach PKB wprawdzie jest prawie dwukrotnie wyższy aniżeli w Grecji, ale był on niższy w 2011 niż w 2002 r. Jeśli chodzi o pozostałe kraje, to plasują się one między tymi dwoma grupami. Na podstawie danych dla 2011 r. trudno jest ustalić, które z nich pójdą w kierunku pierwszej, a które drugiej grupy. Od tego wyboru zależeć będzie przyszła konkurencyjność UE.

\section{IV. „NOWOCZESNOŚĆ” EKSPORTU DÓBR I USEUG: IMPLIKACJE DLA KONKURENCYJNOŚCI}

Utrzymanie przewagi konkurencyjnej $\mathrm{w}$ decydującej mierze zależy od przesuwania się firm do sfer działalności wymagających coraz bardziej zaawansowanych technologii oraz specjalnych kwalifikacji siły roboczej. Jeśli chodzi o produkcje przemysłowa, to rozróżnienie nowoczesnych i tradycyjnych produktów staje się coraz trudniejsze ze względu na powszechne zastosowania elektroniki, zmieniającej nawet tradycyjny czajnik w cacko technologiczne.

11 Ostateczna ocena wymagałaby osobnej analizy czynników, które doprowadziły do załamania się eksportu Rumunii nie tylko podczas kryzysu światowego handlu zagranicznego, w 2009 r., lecz także do jeszcze większego spadku w 2010 r. 
Niemniej można wyróżnić sektory, których funkcjonowanie wymaga nie tylko kapitału, lecz także nowych technologii i specjalnych kwalifikacji siły roboczej do ich utrzymania. Wyodrębniliśmy 18 sektorów standardowej klasyfikacji produktów, używanej w statystykach handlu międzynarodowego, z których wytwarzaniem wiąże się zastosowanie wysokich technologii. Sektory te obejmuja produkcję materiałów radioaktywnych, lekarstw, różnego typu maszyn oraz urządzeń, urządzeń dla lotnictwa i fotografii oraz różnego typu skomplikowanych urządzeń pomiarowych.

Natomiast standardowe klasyfikacje usług w statystykach Międzynarodowego Funduszu Walutowego rozróżniają tradycyjne usługi i usługi nowoczesne. Usługi tradycyjne to transport, turystyka, usługi budowlane oraz usługi kulturalne i rozrywkowe. Usługi nowoczesne obejmuja natomiast opłaty licencyjne, różnego typu royalties (prawa autorskie), ubezpieczenia, telekomunikację oraz usługi związane $\mathrm{z}$ Internetem i oprogramowaniem komputerów i innych urządzeń. Zarówno w jednych, jak i w drugich kraje UE wydają się tracić przewagę konkurencyjna, a przynajmniej jej nie zwiększaja, w stosunku do reszty świata.

\section{Handel produktami o bardziej zaawansowanej technologii}

Eksport takich wyrobów z UE rósł wolniej zarówno od eksportu całkowitego UE, jak i eksportu światowego, choć zmieniało się to z roku na rok. Jedyny okres szybszego ich wzrostu to lata 2004-2006 (wykres 2). Wyroby te okazały się bardziej odporne na załamanie 2009 r.: wartość ich eksportu spadła o $12 \%$ w porównaniu z 23-procentowym załamaniem się eksportu całkowitego dóbr z Unii. Udział UE $\mathrm{w}$ eksporcie światowym tych usług spadł z 38\% w 2002 do $34 \%$ w 2011 r.

Nie tylko osłabła dynamika eksportu dóbr o zaawansowanej technologii, lecz także w ciągu ostatniego dziesięciolecia pogorszył się bilans handlu UE wyrobami zaawansowanej technologii, ale -jak zobaczymy niżej - tylko z uwagi na przesunięcie Wielkiej Brytanii z pozycji eksportera netto do pozycji importera netto. Wprawdzie UE pozostaje eksporterem netto tych wyrobów, tzn. ich eksport był większy od ich importu, ale nadwyżka się zmniejszyła. Nadwyżka eksportu na importem w stosunku do całości obrotu tymi towarami spadła z $2 \%$ w 2002 r. do $1 \%$ w 2009 i 2011 r.

W biedniejszych krajach UE bezpośrednie inwestycje zagraniczne były głównym motorem produkcji i eksportu wyrobów o bardziej zaawansowanej technologii. Historycznie był to wypadek Irlandii, która stała się istotna platformą eksportu tych produktów w latach dziewięćdziesiątych. W ostatniej dekadzie napływ inwestycji do krajów Europy Środkowo-Wschodniej stał się siłą napędzająca tego handlu: spośród 10 krajów UE, które zarejestrowały najszybszy wzrost eksportu produktów zaawansowanej technologii w Unii, osiem to kraje Europy Środkowej (Słowacja - średnio 31\% rocznie w latach 2002-2011; Rumunia - 25,7\%; Łotwa - 24,3\%; Polska i Bułgaria - 23\% oraz Litwa i Węgry - 13\%. Pozostałe dwa kraje to Cypr (15\%) oraz Grecja (11\%). W eksporcie takich dóbr z Cypru ich udział wyniósł $24 \%$, a Grecji -zaledwie $8 \%$. Grecja pozostała największym importerem netto tych produktów w ramach 


\section{Wykres 2}

Eksport dóbr UE, całkowity oraz wysokich technologii, jak również ich udział w eksporcie całkowitym w latach 2001-2011 (w mld dolarów USA oraz w procentach)

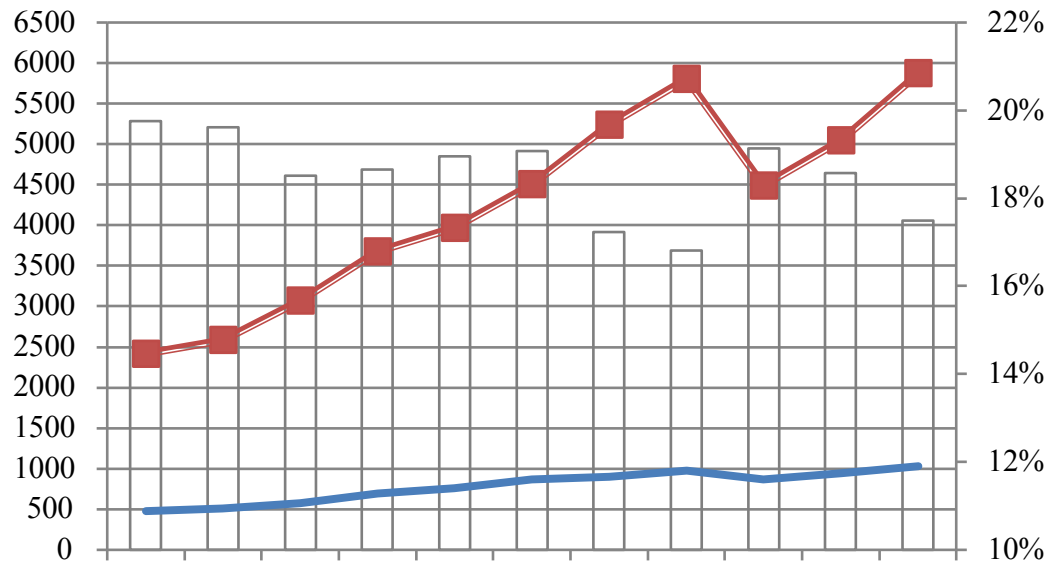

20012002200320042005200620072008200920102011

Udział produktów wysokich technologii w eksporcie (w procentach)

Eksport wys. technologii (w mld dolarów USA)

Całkowity eksport (w mld dolarów USA)

Źródło: obliczenia własne na podstawie danych UN Comtrade.

Unii - wartość wskaźnika eksportu netto wynosiła -0,56 w 2011 r. Podsumowując, sektor przemysłowy UE oraz handel wyrobami przemysłu pozostaje konkurencyjny międzynarodowo, choć jego dynamika jest wolniejsza niż przeciętna dla świata. Jak konkluduja autorzy Raportu Banku Światowego: „Fabryka Azja rośnie szybciej, ale wyroby przemysłowe w handlu w Europie sa znacznie bardziej wyrafinowane" ${ }^{12}$. Pytanie oczywiste - na które nie mamy tu odpowiedzi - to, jak długo kraje UE utrzymają tę przewagę.

\section{Rola usług w handlu zagranicznym państw UE}

Powyższa obserwacja dotyczy również handlu usługami z jednym zastrzeżeniem: handel usługami w Azji nie wydaje się rosnąć tak szybko jak w Europie, choć w obydwu regionach rozwój nowoczesnych usług wydaje się kuleć. Według różnych ocen jednolity rynek europejski sprzyja rozwojowi wymiany w takich usługach, jak transport oraz turystyka, natomiast nie sprzyja rozwojowi wymiany w dziedzinie oprogramowania komputerowego, rozwoju software dla zastosowań internetowych, usług biznesowych związanych z przetwarzaniem informacji, obsługa finansowa itp., czyli tzw. usług nowoczesnych, wymagających na ogół kapitału ludzkiego o wysokich kwalifikacjach.

12 I. Gil, M. Raiser, op. cit., s. 41. 


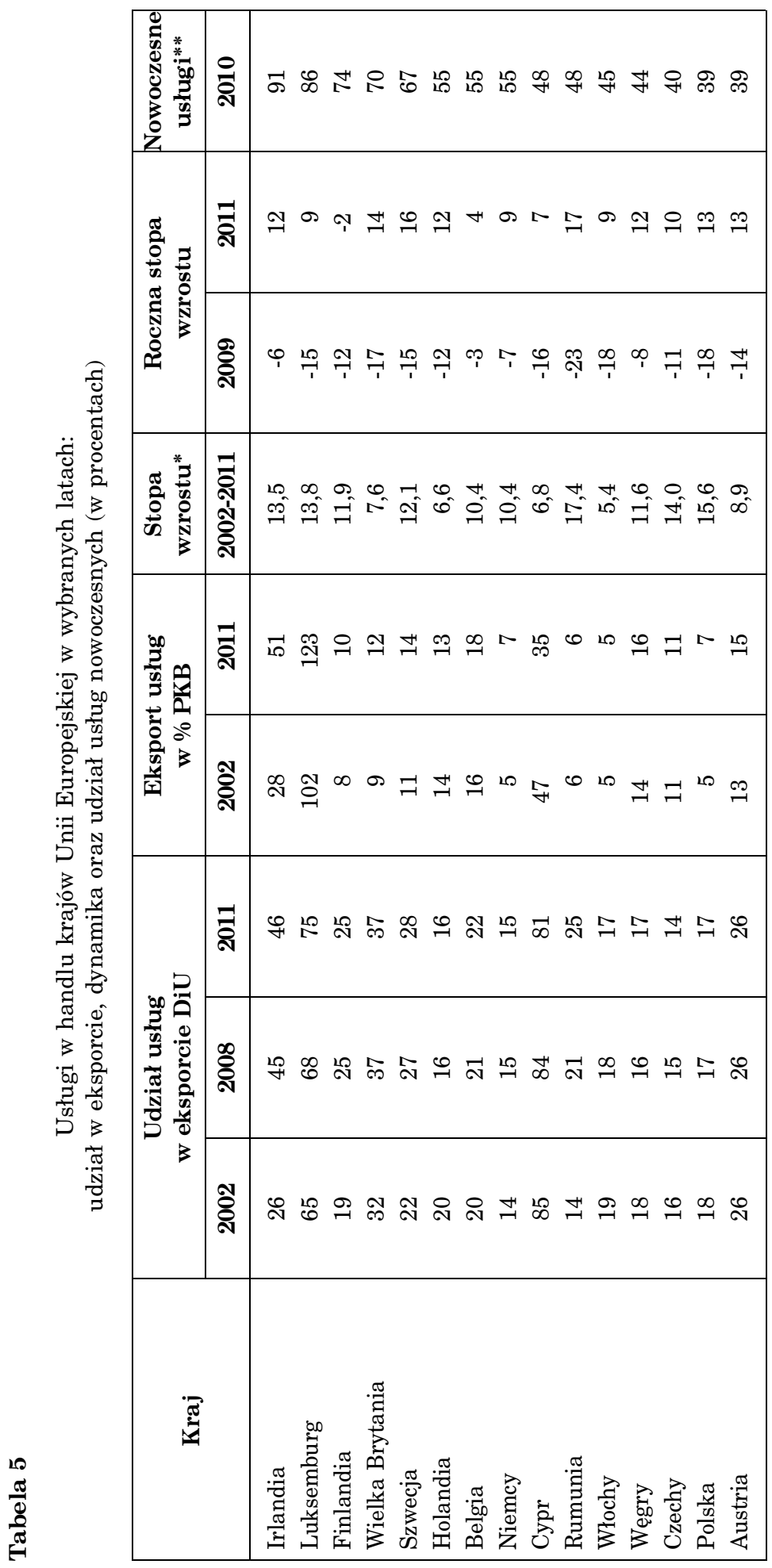




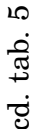

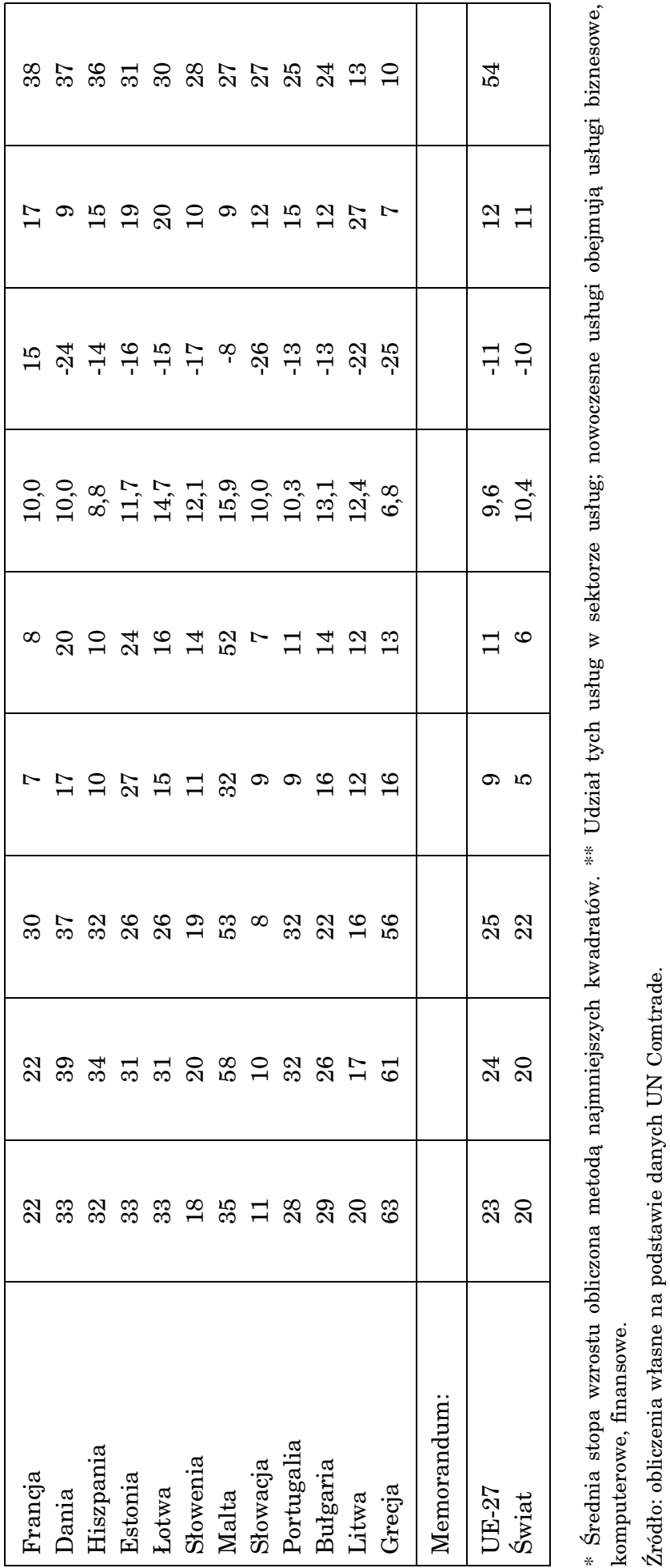


Handel usługami krajów UE wzrastał w pierwszym dziesięcioleciu XXI w. szybciej aniżeli międzynarodowe obroty towarowe. Ich udział w całkowitym eksporcie UE wzrósł z 23\% do 25\%. Ponadto Unia, jako całość, tradycyjnie była i nadal jest eksporterem netto usług: eksport usług był na ogół ok. $20 \%$ wyższy od ich importu. Eksport usług UE w procencie zagregowanego PKB dla UE wzrósł z 9\% w 2002 r. do 11\% w 2012 r. (tab. 5). Luksemburg, Malta oraz Irlandia mają największy eksport usług w kategoriach udziału tego eksportu w PKB. Eksport usług przekroczył PKB Luksemburga o 23\% w 2011 r. Wynosił on $52 \%$ PKB Malty oraz 51\% PKB Irlandii.

Rola sektora usług $\mathrm{w}$ gospodarce narodowej zależy od wielu czynników: geografii wraz z warunkami naturalnymi, dziedzictwa historii, jakości infrastruktury i kapitału ludzkiego, i oczywiście, w jak największym skrócie, od poziomu rozwoju gospodarczego kraju. Pierwsze dwa wpływaja na turystykę oraz dochody z transportu, a pozostałe wyznaczaja partycypacje firm danego kraju w usługach finansowych, informatycznych oraz innych usług biznesowych. O ile pierwsze są usługami tradycyjnymi, o tyle druga grupa odnosi się do usług nowoczesnych zależnych od poziomu rozwoju kraju. Istotnie nawet pobieżna analiza danych przedstawionych $\mathrm{w}$ tabeli 5 wskazuje na dodatnia korelację między poziomem rozwoju kraju a udziałem usług nowoczesnych w całości podaży usług. Wśród krajów, w których udział ten przekracza 50\%, sa wyłącznie wysoko rozwinięte kraje północnej Europy, w tym Niemcy. Natomiast w grupie gospodarek, w których udział tego sektora wynosi $25 \%$ lub mniej, można znaleźć - z wyjątkiem Litwy - kraje atrakcyjne turystycznie, o relatywnie niższym poziomie PKB per capita, z południowych peryferii Unii Europejskiej.

Tak jak to miało miejsce w wypadku eksportu produktów o wyższym nasyceniu techniką, największą dynamikę wzrostu eksportu usług zarejestrowały kraje Europy Środkowo-Wschodniej (z wyjątkiem Słowacji i Cypru), a następnie Luksemburg, Irlandia oraz Szwecja. Bezpośrednie inwestycje zagraniczne były motorem zmian technologicznych w krajach o niższym poziomie rozwoju gospodarczego ${ }^{13}$.

\section{PODSUMOWANIE}

Wprawdzie nic nie wskazuje, aby UE osiagnęła cel przyjęty przez Radę Europejską w Lizbonie w 2000 r., czyli przekształcenia Europy w ,,...] najbardziej konkurencyjna oraz dynamiczna, opartą na wiedzy, gospodarkę na świecie" ${ }^{14}$, ale Unia nie wpadła w inną pułapkę, a mianowicie: specjalizowania się we wzajemnej wymianie produktów oraz usług sprzedawanych po cenach

\footnotetext{
${ }^{13}$ B. Javorcik, B. Kaminski, Multinational Corporations and Export Competitiveness, w: J. Winiecki (red.), Competitiveness of New Europe, Routledge, London-New York 2009.

${ }^{14}$ Lisbon European Council 23 and 24 March 2000 Presidency Conclusions, http://www. europarl.europa.eu/summits/lis1_en.htm.
} 
znacznie przewyższających ich wartość na rynkach globalnych ${ }^{15}$. Firmy z UE wykazały zadziwiająca zdolność utrzymania przewagi konkurencyjnej w czterech przemysłach, które tradycyjnie wyznaczały ich profil specjalizacji: wyroby chemiczne, środki transportu, urządzenia elektryczne i optyczne oraz maszyny nieelektryczne.

Włączenie firm z krajów Europy Środkowo-Wschodniej w łańcuchy dostawcze zachodnioeuropejskich multinationals dodatkowo przyczyniło się do zwiększenia ich siły konkurencyjnej, a poza tym stworzyło nowe pola ekspansji eksportowej. Jednocześnie takie kraje, jak Finlandia, Szwecja, Wielka Brytania, Dania i Irlandia, odnotowały znaczny wzrost eksportu nowoczesnych usług.

Kraje UE zwiększyły stopień otwarcia mierzony eksportem w procencie PKB nie tylko wobec siebie, lecz także wobec świata i jednocześnie wzrosła ich partycypacja $\mathrm{w}$ międzynarodowym podziale pracy. Udział UE $\mathrm{w}$ handlu światowym dóbr i usług utrzymał się w przybliżeniu na tym samym poziomie (ok. 40\%). Zważywszy na trwająca ekspansję eksportu Chin, stanowi to godne odnotowania osiagnięcie. Ponadto warto odnotować, że eksport do UE rósł wolniej od eksportu do reszty świata.

Podczas gdy wiele różnych czynników kształtowało eksport poszczególnych krajów, przynależność do strefy euro nie była czynnikiem wyróżniającym. Wprawdzie wspólna waluta największych ekonomicznie krajów Unii znacznie obniżyła koszty transakcyjne i w tym sensie miała pozytywny wpływ na rozwój handlu wewnątrz Unii, ale wśród krajów o bardzo dobrych wynikach zewnętrznych są zarówno kraje strefy euro, jak i spoza niej. Istnienie strefy euro miało bardzo pozytywny wpływ na handel krajów Europy Środkowo-Wschodniej. Nie był to oczywiście jedyny powód, dla którego kraje te zarejestrowały najszybszy wzrost eksportu. Chociaż wśród pięciu krajów, których eksport dóbr i usług wzrósł najwięcej wśród krajów Unii w latach 2002-2011, nie było żadnego kraju, który przyjął euro, to głównymi odbiorcami ich eksportu były kraje strefy euro. W kontekście wyników eksportowych krajów Europy Środkowo-Wschodniej wydaje się, że najważniejszą determinantę stanowił jednolity rynek.

Paradoksalnie istnienie wspólnej waluty euro, a raczej rozluźnienie dyscypliny finansowo-budżetowej związane z jej wprowadzeniem, zagraża rozwojowi sektora prywatnego. Autorzy raportu Komisji Europejskiej o konkurencyjności Europy konkluduja, że ,[...] modernizacja bazy przemysłowej oraz usunięcie instytucjonalnych barier przedsiębiorczości są najważniejsze dla konkurencyjności europejskich przedsiębiorstw w Europie i poza jej granicami" ${ }^{16}$. Sedno sprawy w tym, że dopóki sektor publiczny będzie wypychał sektor prywatny z rynków finansowych, dopóty modernizacja bazy przemysłowej będzie mocno utrudniona.

\footnotetext{
15 D. Roche, op. cit.

${ }^{16}$ European Competitiveness Report 2012/Reaping the Benefits of Globalization, European Commission, Brussels, s. 1.
} 
Wyzwanie na przyszłość to prowadzenie polityki prowzrostowej, z czym nieuchronnie wiązać się powinno ograniczenie ekspansji sektora publicznego, widocznego w szybko narastającym zadłużeniu.

prof. dr hab. Barttomiej Kamiński

Uniwersytet Marylandu w College Park

oraz Wyższa Szkota Informatyki i Zarzadzania w Rzeszowie

bkaminski71@gmail.com

dr Francis $\mathrm{Ng}$

Ekonomia Rozwoju, Grupa Badań Handlu, Bank Swiatowy, Waszyngton

fng@worldbank.org

\section{EURO CRISIS AND FOREIGN TRADE OF THE EU MEMBER STATES}

\section{Summary}

Euro crisis so far appears not to have had any significant impact on the EU's foreign trade performance: its standing in world trade has not moved. Yet, the crisis has exacerbated differences in the external performance. Three groups have emerged: stagnant economies of the Southern periphery of the EU; a dynamic New Europe; and a stable North. Neither the Euro nor the financial global crisis has changed the weight of the EU in world trade. They did not reverse the trend of the growing openness of the EU member states' economies in the 2000s. It was exports, rather than the domestic demand, that drove the economic growth of the EU economies during this period. Empirical data do not corroborate commentaries about cheap Euro loans having been used to finance the German export expansion in the EU southern periphery. To the contrary, the share of these countries in German exports fell during the 'Euro' period to below 15 per cent. Expectations of dramatic increases in trade among Euro economies turned out to be ill-founded. But foreign trade performance of the new EU member states from Central Europe was superior to that of the 'old' EU countries. The challenge for these countries, however, shall be not to 'borrow' any of the anti-growth policies implemented in some other EU member states, which could otherwise lead to disappearance of the once positive effects of the Single Market. 
Copyright of Journal of Law, Economics and Sociology is the property of Faculty of Law and Administration of Adam Mickiewicz University in Poznan and its content may not be copied or emailed to multiple sites or posted to a listserv without the copyright holder's express written permission. However, users may print, download, or email articles for individual use.

Właścicielem praw autorskich do „Ruchu Prawniczego, Ekonomicznego i Socjologicznego” jest Wydział Prawa i Administracji Uniwersytetu im. Adama Mickiewicza w Poznaniu. Zawartość czasopisma nie może być kopiowana, przesyłana do innych stron internetowych bądź zamieszczana na blogach bez pisemnej zgody wydawcy. Niemniej artykuły można drukować, kopiować lub przesyłać w formie elektronicznej na własny użytek. 